The knowledge engineering review

VOLUME 26 NUMBER 4 DECEMBER $201 \mathrm{I}$ 


\title{
The knowledge engineering review
}

EDITORS

Professor Simon Parsons, City University of New York, USA

Dr Peter McBurney, Kings College London, UK

TUTORIALS EDITOR

Dr Iyad Rahwan, Masdar Institute of Science and Technology

FOUNDING EDITOR

Professor John Fox, University of Oxford, UK

EDITORIAL BOARD

Professor Jacky Baltes

University of Manitoba, Canada

Professor J. Christopher Beck

University of Toronto, Canada

Dr Patrick Brézillon

University Paris, France

Professor Odest Chad Jenkins

Brown University, USA

Professor Xiaoping Chen

University of Science and Technology of China

Dr Frans Coenen

University of Liverpool, $U K$

Dr Stephen Cranefield

University of Otago, New Zealand

Professor Keith Decker

University of Delaware, USA

Professor Noémie Elhadad

Columbia University, USA

Dr Maria Fasli

Essex University, $U K$

Dr Yolanda Gil

University of Southern California, USA

Professor C. Lee Giles

The Pennsylvania State University, USA

Dr Carla Gomes

Cornell University, USA

\author{
Dr Anthony Hunter \\ University College London, UK \\ Professor Kate Larson \\ University of Waterloo, Canada \\ Professor Khaled Mellouli \\ Institute des Hautes Edudes Commerciales, Tunisia \\ Professor Ann Nicholson \\ Monash University, Australia \\ Dr Ann Nowe \\ VUB, Brussels, Belgium \\ Professor Alun Preece \\ Cardiff University, UK \\ Dr Juan Antonio Rodriguez-Aguilar \\ Artificial Intelligence Research Institute, Spain \\ Dr Sandip Sen \\ University of Tulsa, USA \\ Professor Jaime Sichman \\ University of São Paulo, Brazil \\ Professor Guillermo Simari \\ Universidad Nacional del Sur, Argentina \\ Professor Liz Sonenberg \\ University of Melbourne, Australia \\ Dr Mirko Viroli \\ University of Bologna - Cesena, Italy \\ Dr Rogier van Eijk \\ Utrecht University, the Netherlands
}

\section{The Knowledge Engineering Review: Publication Policy}

The Knowledge Engineering Review has been established to provide a general source of information and analysis in all areas relevant to research and development in knowledge based systems and applied artificial intelligence. The editors wish to encourage careful preparation of original papers analysing developments in the field. In particular we wish to see tutorial and survey articles, and commentary, criticism and debate. Primary research papers on specialised technical topics are unlikely to be appropriate but research papers on broad topics, such as development methodology or general evaluations of tools and techniques, are of interest. Descriptions of specific projects or particular computer systems will be considered if their presentation draws out general issues in the design, implementation or impact of knowledge based systems.

\section{Subscriptions}

THE KNOWLEDGE ENGINEERING REVIEW (ISSN 0269-8889) is published quarterly in March, June, September and December. Four parts form a volume. Orders, which must be accompanied by payment, should be sent to any bookseller or subscription agent, or direct to Cambridge University Press, The Edinburgh Building, Shaftesbury Road, Cambridge CB2 8RU. Subscriptions in the USA or Canada should be sent to Cambridge University Press, 100 Brook Hill Drive, West Nyack, New York 10994-2133. The subscription price (which includes delivery by air where appropriate plus electronic access to institutional subscribers, but excludes VAT) of volume 26, 2011 is $£ 375$ (US\$680 in the USA and Canada) for institutions; $£ 105$ (US\$185 in the USA and Canada) for individuals, including postage; separate parts cost $£ 95$ (US\$165 in the USA and Canada) plus postage. EU subscribers (outside the UK) who are not registered for VAT should add VAT at their country's rate. VAT registered subscribers should provide their VAT registration number.

Japanese prices for institutions are available from Kinokuniya Company Ltd, P.O. Box 55, Chitose, Tokyo 156, Japan. POSTMASTER: send address changes in USA and Canada to The Knowledge Engineering Review, Cambridge University Press, 100 Brook Hill Drive, West Nyack, New York 10994-2133.

\section{Copying}

This journal is registered with the Copyright Clearance Center, 222 Rosewood Drive, Danvers, MA 01923. Organisations in the USA, also registered with the C.C.C., may therefore copy material (beyond the limits permitted by sections 107 and 108 of US copyright law) subject to payment to C.C.C. of the per-copy fee of $\$ 12.00$. This consent does not extend to multiple copy for promotional or commercial purposes. Code 0269-8889/2011 \$12.50+0.10.

FOR ALL OTHER USE, permission should be sought from the Cambridge or New York offices of the Cambridge University Press. CLAIMS for missing issues can only be considered if made immediately after receipt of the subsequent issue.

BACK VOLUMES: Volumes 1-7 are available from Swets and Zeitlinger at P.O. Box 810, 2160 SZ Lisse, The Netherlands. Volumes 8-25 are available from Cambridge University Press.

ADVERTISING: Details of advertising in The Knowledge Engineering Review may be obtained from the publisher.

Information on The Knowledge Engineering Review and all other Cambridge journals can be accessed via journals.cambridge.org. For further information on other Press titles access journals.cambridge.org

INTERNET ACCESS. This journal is included in the Cambridge Journals Online service which can be found at journals.cambridge.org/ker 